\title{
Effect of Sequential Application of Herbicides on Weed Density, Weed Dry Weight and Yield of Irrigated Maize
}

\author{
R. Arockia Infant Paul ${ }^{1 *}$, G. Srinivasan ${ }^{2}$, A. Veeramani ${ }^{1}$ and R. Thamizh Vendan ${ }^{3}$ \\ ${ }^{1}$ Department of Agronomy, ${ }^{3}$ Department of Agricultural Microbiology, Agricultural College \\ and Research Institute, Madurai, India \\ ${ }^{2}$ Regional Research Station, Aruppukottai, India \\ *Corresponding author
}

\section{A B S T R A C T}

\section{Keywords}

Weed density, Weed dry weight, Halosulfuron methyl, Pre emergence, Post emergence and Tembotrione

Article Info

Accepted:

10 September 2020 Available Online: 10 October 2020
A field experiment was conducted to evaluate the effect of sequential application of herbicides on weed density, weed dry weight and yield of irrigated maize during kharif season, 2019-2020 at Agricultural College and Research Institute, Madurai, Tamil Nadu. In maize field, lesser number of weeds $\mathrm{m}^{-2}$ and weed dry weight $\mathrm{m}^{-2}$ were observed in weed free check and was followed by pre emergence application of atrazine at $0.25 \mathrm{~kg}$ a.i ha ${ }^{-1}$ at 3 DAS followed by post emergence application of tembotrione at $120 \mathrm{~g}^{\mathrm{a} . \mathrm{iha}^{-1}}$ at $25 \mathrm{DAS}$ $\left(\mathrm{T}_{3}\right)$.The highest maize grain yield was obtained in weed free check $\left(\mathrm{T}_{7}\right)$ which was statistically on par with treatment pre emergence atrazine $0.25 \mathrm{~kg} \mathrm{ha}^{-1}$ followed by post emergence tembotrione $120 \mathrm{~g} \mathrm{ha}^{-1}\left(\mathrm{~T}_{3}\right)$, pre emergence pendimethalin $1 \mathrm{~kg} \mathrm{ha}^{-1}$ followed by post emergence tembotrione $120 \mathrm{~g} \mathrm{ha}^{-1}\left(\mathrm{~T}_{4}\right)$, pre emergence atrazine $0.25 \mathrm{~kg} \mathrm{ha}^{-1}$ followed by post emergence halosulfuron methyl $90 \mathrm{~g} \mathrm{ha}^{-1}\left(\mathrm{~T}_{5}\right)$ and pre emergence pendimethalin 1 $\mathrm{kg} \mathrm{ha}{ }^{-1}$ followed bypost emergence halosulfuron methyl $90 \mathrm{~g} \mathrm{ha}^{-1}\left(\mathrm{~T}_{6}\right)$. During the experimentation highest $\mathrm{B}$ : $\mathrm{C}$ ratio was obtained in atrazine at $0.25 \mathrm{~kg}$ a.i ha ${ }^{-1}$ at 3 DAS followed by post emergence application of tembotrione at $120 \mathrm{~g}$ a.iha ${ }^{-1}$ at $25 \mathrm{DAS}\left(\mathrm{T}_{3}\right)$ and was followed by preemergence application of pendimethalin at $1 \mathrm{~kg} \mathrm{ha}^{-1}$ followed by post emergence application of tembotrione at $120 \mathrm{~g} \mathrm{a.iha}^{-1}$ at $25 \mathrm{DAS}\left(\mathrm{T}_{4}\right)$.

\section{Introduction}

Maize (Zea mays L.) is the third most important cereal crops in India after rice and wheat with respect to agricultural economy. The plant is considered as a "Queen of cereals" and "Miracle crop" due to its versatilite nature and highest genetic yield potential. In India, maize was cultivated in an area of 9.28 million hectares with a production of 27.72 million tonnes and average productivity of $2890 \mathrm{~kg} \mathrm{ha}^{-1}$ during 2018-19. In India, productivity of maize is low as compared to world productivity, which can be attributed by several limiting factors. Among all weed infestation and poor weed management practices poses yield reduction. Nazreen et al., (2018) reported that 
the yield loss in maize caused by weeds extended up to 28 to 93 per cent depending on the type of weed flora, intensity and duration of crop weed competition. Singh et al., (2015) observed the emergence of maize and weeds were simultaneous and found that the first 2030 days were the most critical period of competition for the crop. During this critical period crop should free from weed competition for optimum crop growth and yield. Therefore, necessary weeding practices followed to control the weeds. Hand weeding and mechanical weeding are expensive, time consuming, and labour intensive. Herbicides are one of the crucial factors to increase the production of cereals. Herbicide application is easier and economical to farmers compared to other weed management practices. Hence the preset study deals with the effect of different weed management practices on weed density, weed dry weight and grain yield of maize.

\section{Materials and Methods}

A field experiment was conducted in kharif, 2019-2020at Agricultural College and Research Institute, Madurai to study the effect of sequential application of herbicides on weed density, weed dry weight and yield of maize under irrigated condition. TNAU maize hybrid Co-6 was used for this experiment. The soil texture of the experimental field was sandy clay loam. The experiment was laid out in Randomized Block Design with eight treatments and replicated thrice. The treatments consisted of $\mathrm{T}_{1}$ - Application of atrazine at $0.25 \mathrm{~kg}$ a.i $\mathrm{ha}^{-1}$ as pre emergence (PE) at 3 DAS followed by one hand weeding at $25 \mathrm{DAS}, \mathrm{T}_{2}-$ Application of pendimethalin at $1 \mathrm{~kg}$ a.i ha ${ }^{-1}$ as PE at 3 DAS followed by one hand weeding at $25 \mathrm{DAS}, \mathrm{T}_{3}$ - Application of atrazine at $0.25 \mathrm{~kg}$ a.i ha $\mathrm{ha}^{-1}$ as PE at 3 DAS followed by tembotrione at $120 \mathrm{~g}^{\mathrm{a} . \mathrm{i} \mathrm{ha}} \mathrm{ha}^{-1}$ as post emergence (POE) at 25 DAS, $\mathrm{T}_{4-}$ Application of pendimethalin at $1 \mathrm{~kg} \mathrm{a} \mathrm{i} \mathrm{ha} \mathrm{ha}^{-1}$ as $\mathrm{PE}$ at 3 DAS followed by tembotrione at 120 g a a.i ha ${ }^{-1}$ as POE at 25 DAS, T $5^{-}$
Application of atrazine at $0.25 \mathrm{~kg}$ a.i ha ${ }^{-1}$ as $\mathrm{PE}$ at 3 DAS followed by halosulfuron methyl at $90 \mathrm{~g}$ a.i $\mathrm{ha}^{-1}$ as POE at $25 \mathrm{DAS}^{-\mathrm{T}_{6}}$ Application of pendimethalin at $1 \mathrm{~kg}$ a.i ha ${ }^{-1}$ as PE at 3 DAS followed by halosulfuron methyl at $90 \mathrm{~g}$ a.i ha ${ }^{-1}$ as POE at $25 \mathrm{DAS} \mathrm{T}_{7-}$ Weed free check, $\mathrm{T}_{8}$ - Unweeded check. All the herbicides were applied uniformly in the experimental plots with the help of knapsack sprayer. All the recommended agronomic and plant protection measures were adopted to raise the crop. Observations on weed parameters viz., weed density and weed dry weight were recorded. Weed count was recorded by placing four quadrats of size 0.5 $\mathrm{m} \times 0.5 \mathrm{~m}$ in each plot and the weeds falling within the frames of the quadrat were counted, recorded and the mean values expressed in number $\mathrm{m}^{-2}$. The weeds falling within the frames of the quadrats were collected and dried in hot-air oven at $80^{\circ} \mathrm{C}$ for $72 \mathrm{hrs}$. The weed density and weed dry weight were analyzed after subjecting the original data to square root transformation $[\sqrt{ } \mathrm{x}+0.5]$. The treatment effects were compared using transformed means. The experimental data obtained during the course of investigation were subjected to statistical analysis following the procedure of Gomez and Gomez (1984).

\section{Results and Discussion}

\section{Weed flora}

Major weed flora of the experimental field were Dactyloctenium aegyptiumand Echinochloa colonumin grasses, Cyperus esculentus and Cyperus rotundus in sedges and Acalypha indica, Boerhavia erecta, Cleome viscosa, Commelina benghalensis, Croton sparsiflorus, Eclipta alba, Phyllanthus maderaspatensis, Phyllanthus niruri and Trianthema portulacastrum in broad leaved weeds. 


\section{Weed density and weed dry weight}

The weed density and weed dry weight significantly reduced by weed management practices (Table 1). At 20 days after sowing, lowest weed density and dry weight were recorded in weed free condition $\left(\mathrm{T}_{7}\right)$ and was followed by the application of atrazine at 0.25 $\mathrm{kg}$ a.i ha $\mathrm{h}^{-1}$ as PE at 3 DAS followed by tembotrione at $120 \mathrm{~g}$ a.i ha ${ }^{-1}$ as POE at 25 DAS $\left(T_{3}\right)$. At 60 DAS, lowest weed density and dry weight were recorded in weed free condition $\left(\mathrm{T}_{7}\right)$ and was followed by the application of atrazine at $0.25 \mathrm{~kg}$ a.i ha ${ }^{-1}$ as $\mathrm{PE}$ at 3 DAS followed by tembotrione at 120 g a.i ha ${ }^{-1}$ as POE at 25 DAS $\left(\mathrm{T}_{3}\right)$ and was on par with application of pendimethalin at 1.0 $\mathrm{kg}$ a.i ha ${ }^{-1}$ as PE at 3 DAS followed by tembotrione at $120 \mathrm{~g}$ a.i $\mathrm{ha}^{-1}$ as POE at 25 DAS $\left(\mathrm{T}_{4}\right)$.Among the different herbicides, application of tembotrione as post emergence significantly reducing the grassy and nongrassy weeds by inhibits the 4hydroxyphenyl-pyruvatedioxygenase (4HPPD) enzymes which causes lack of electron acceptor in photosynthesis. Similar findings are recorded by Sonali Biswas et al., (2018). Highest weed density and dry weight were observed in unweed check $\left(\mathrm{T}_{8}\right)$ (Fig. 1).

\section{Yield attributes}

The data on the yield attributes are presented in Table 2. Weed management practices had a positive influence on maize yield. Highest maize grain yield was recorded in weed free check $\left(\mathrm{T}_{7}\right)$, which was mainly due to minimum crop weed competition throughout the crop growth period, thus enabling the crop for maximum utilization of nutrients, moisture, light and space which favoured growth and yield components. The results are in accordance with the findings of Hatti et al., (2014) and Shantveerayyahawaldar and Agasimani (2012). This was at par with PE atrazine $0.25 \mathrm{~kg} \mathrm{ha}^{-1}$ followed by POE tembotrione $120 \mathrm{~g} \mathrm{ha}^{-1}\left(\mathrm{~T}_{3}\right)$, PE pendimethalin $1 \mathrm{~kg} \mathrm{ha}^{-1}$ followed by POE tembotrione $120 \mathrm{~g}$ $\mathrm{ha}^{-1}\left(\mathrm{~T}_{4}\right), \mathrm{PE}$ atrazine $0.25 \mathrm{~kg} \mathrm{ha}^{-1}$ followed by POE halosulfuron methyl $90 \mathrm{~g} \mathrm{ha}^{-1}\left(\mathrm{~T}_{5}\right)$ and PE pendimethalin $1 \mathrm{~kg} \mathrm{ha}^{-1}$ followed byPOE halosulfuron methyl $90 \mathrm{~g} \mathrm{ha}^{-1}\left(\mathrm{~T}_{6}\right)$.

Fig.1 Effect of weed density and weed dry weight on grain yield

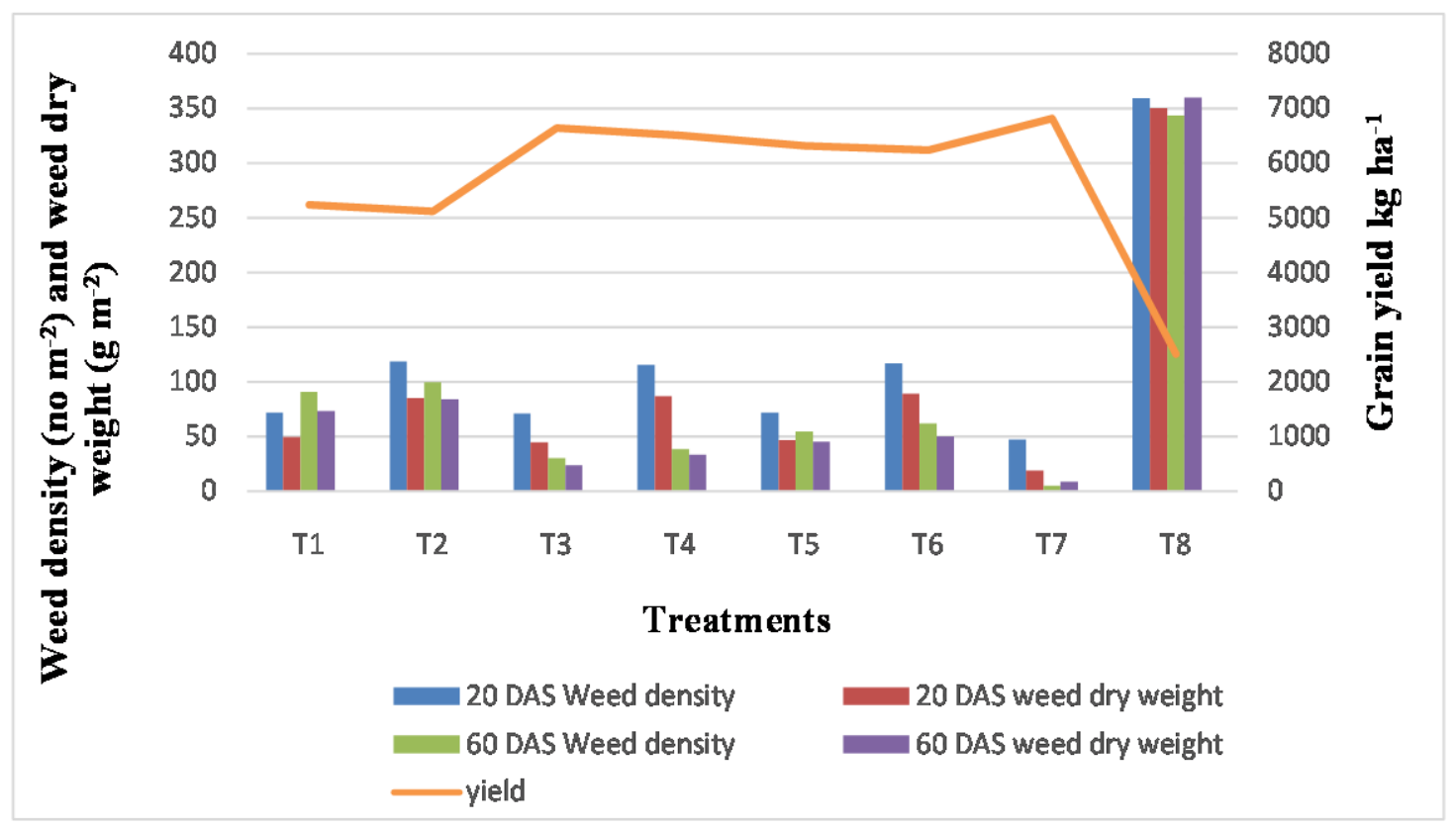


Table.1 Effect of weed management on weed density and weed dry weight in maize at 20 and 60 DAS

\begin{tabular}{|c|c|c|c|c|}
\hline \multirow[t]{2}{*}{ Treatment } & \multicolumn{2}{|c|}{ Weed density $\left(\mathrm{No} / \mathrm{m}^{-2}\right)$} & \multicolumn{2}{|c|}{ Weed dry weight $\left(\mathrm{g} / \mathrm{m}^{-2}\right)$} \\
\hline & 20 DAS & 60 DAS & 20 DAS & 60 DAS \\
\hline $\begin{array}{l}T_{1:} \text { PE atrazine at } 0.25 \mathrm{~kg} \mathrm{ha}^{-1} f b \text { hand } \\
\text { weeding at } 25 \text { DAS }\end{array}$ & $\begin{array}{l}71.67 \\
(8.49)\end{array}$ & $\begin{array}{l}91.00 \\
(9.56)\end{array}$ & $\begin{array}{l}49.60 \\
(7.07)\end{array}$ & $\begin{array}{l}73.52 \\
(8.60)\end{array}$ \\
\hline $\begin{array}{l}\mathrm{T}_{2:} \text { PE pendimethalin at } 1 \mathrm{~kg} \mathrm{ha}^{-1} \mathrm{fb} \text { hand } \\
\text { weeding at } 25 \text { DAS }\end{array}$ & $\begin{array}{l}118.67 \\
(10.90)\end{array}$ & $\begin{array}{c}99.67 \\
(10.00)\end{array}$ & $\begin{array}{l}85.19 \\
(9.25)\end{array}$ & $\begin{array}{l}83.93 \\
(9.18)\end{array}$ \\
\hline $\begin{array}{l}\mathrm{T}_{3:} \mathrm{PE} \text { atrazine at } 0.25 \mathrm{~kg} \mathrm{ha}^{-1} \mathrm{fb} \text { POE } \\
\text { tembotrione } 120 \mathrm{~g} \mathrm{ha}^{-1}\end{array}$ & $\begin{array}{l}71.00 \\
(8.43)\end{array}$ & $\begin{array}{l}30.00 \\
(5.50)\end{array}$ & $\begin{array}{l}44.72 \\
(6.72)\end{array}$ & $\begin{array}{l}23.66 \\
(4.91)\end{array}$ \\
\hline $\begin{array}{l}\mathrm{T}_{4:} \text { PE pendimethalin at } 1 \mathrm{~kg} \mathrm{ha}^{-1} \mathrm{fb} \text { POE } \\
\text { tembotrione } 120 \mathrm{~g} \mathrm{ha}^{-1}\end{array}$ & $\begin{array}{l}115.33 \\
(10.72)\end{array}$ & $\begin{array}{l}38.33 \\
(6.23)\end{array}$ & $\begin{array}{l}86.99 \\
(9.35)\end{array}$ & $\begin{array}{l}33.27 \\
(5.81)\end{array}$ \\
\hline $\begin{array}{l}\mathrm{T}_{5: \mathrm{PE}} \text { atrazine at } 0.25 \mathrm{~kg} \mathrm{ha}^{-1} \mathrm{fb} \text { POE } \\
\text { halosulfuron methyl } 90 \mathrm{~g} \mathrm{ha}^{-1}\end{array}$ & $\begin{array}{l}72.00 \\
(8.50)\end{array}$ & $\begin{array}{l}54.67 \\
(7.42)\end{array}$ & $\begin{array}{l}46.83 \\
(6.87)\end{array}$ & $\begin{array}{l}45.20 \\
(6.75)\end{array}$ \\
\hline $\begin{array}{l}\text { T}_{6:} \text { PE pendimethalin at } 1 \mathrm{~kg} \mathrm{ha}^{-1} \mathrm{fb} \text { POE } \\
\text { halosulfuron methyl } 90 \mathrm{~g} \mathrm{ha}^{-1}\end{array}$ & $\begin{array}{l}117.00 \\
(10.81)\end{array}$ & $\begin{array}{l}62.00 \\
(7.89)\end{array}$ & $\begin{array}{l}89.11 \\
(9.47)\end{array}$ & $\begin{array}{l}50.16 \\
(7.11)\end{array}$ \\
\hline $\mathbf{T}_{7:}$ Weed free check & $\begin{array}{l}47.33 \\
(6.89)\end{array}$ & $\begin{array}{c}5.33 \\
(2.39)\end{array}$ & $\begin{array}{l}18.87 \\
(4.34)\end{array}$ & $\begin{array}{c}8.92 \\
(3.07)\end{array}$ \\
\hline $\mathbf{T}_{8:}$ Unweeded check & $\begin{array}{l}359.67 \\
(18.95)\end{array}$ & $\begin{array}{l}343.67 \\
(18.53)\end{array}$ & $\begin{array}{l}350.22 \\
(18.70)\end{array}$ & $\begin{array}{l}359.94 \\
(18.97)\end{array}$ \\
\hline SEd & 0.52 & 0.43 & 0.45 & 0.43 \\
\hline CD at $5 \%$ & 1.11 & 0.93 & 0.96 & 0.93 \\
\hline
\end{tabular}

$*(\sqrt{x}+0.5$ Transformed values and Data in parenthesis are original values $)$ 
Table.2 Effect of weed management on yield attributes of maize

\begin{tabular}{|c|c|c|c|}
\hline Treatment & No. of grains $\operatorname{cob}^{-1}$ & 100 grain weight $\mathrm{g}$ & Grain yield kg ha ${ }^{-1}$ \\
\hline $\mathrm{T}_{1:}$ PE atrazine at $0.25 \mathrm{~kg} \mathrm{ha}^{-1} f b$ hand weeding at $25 \mathrm{DAS}$ & 361.37 & 25.03 & 5239 \\
\hline $\begin{array}{l}T_{2:} \text { PE pendimethalin at } 1 \mathrm{~kg} \mathrm{ha}^{-1} \mathrm{fb} \text { hand weeding at } 25 \\
\text { DAS }\end{array}$ & 347.25 & 24.74 & 5117 \\
\hline $\mathrm{T}_{3:} \mathrm{PE}$ atrazine at $0.25 \mathrm{~kg} \mathrm{ha}^{-1} \mathrm{fb}$ POE tembotrione $120 \mathrm{~g} \mathrm{ha}^{-1}$ & 627.83 & 31.74 & 6639 \\
\hline $\begin{array}{l}\mathrm{T}_{4:} \text { PE pendimethalin at } 1 \mathrm{~kg} \mathrm{ha}^{-1} \mathrm{fb} \text { POE tembotrione } 120 \mathrm{~g} \\
\mathrm{ha}^{-1}\end{array}$ & 591.23 & 31.07 & 6510 \\
\hline $\begin{array}{l}\mathrm{T}_{5:} \mathrm{PE} \text { atrazine at } 0.25 \mathrm{~kg} \mathrm{ha}^{-1} \mathrm{fb} \text { POE halosulfuron methyl } \\
90 \mathrm{~g} \mathrm{ha}^{-1}\end{array}$ & 529.05 & 28.53 & 6321 \\
\hline $\begin{array}{l}\text { T}_{6:} \text { PE pendimethalin at } 1 \mathrm{~kg} \mathrm{ha}^{-1} \mathrm{fb} \text { POE halosulfuron } \\
\text { methyl } 90 \mathrm{~g} \mathrm{ha}^{-1}\end{array}$ & 466.96 & 28.07 & 6237 \\
\hline $\mathbf{T}_{7:}$ Weed free check & 665.19 & 32.17 & 6817 \\
\hline $\mathbf{T}_{8:}$ Unweeded check & 272.75 & 18.23 & 2507 \\
\hline SEd & 30.33 & 1.36 & 306 \\
\hline CD at $5 \%$ & 65.06 & 2.91 & 657 \\
\hline
\end{tabular}


Table.3 Effect of weed management on economics

\begin{tabular}{|c|c|c|c|c|}
\hline Treatment & $\begin{array}{l}\text { Cost of } \\
\text { cultivation } \\
\left(\text { Rs. } \text { ha }^{-1}\right)\end{array}$ & $\begin{array}{c}\text { Gross monetary } \\
\text { return } \\
(\text { Rs. ha-1 })\end{array}$ & $\begin{array}{c}\text { Net monetary } \\
\text { return } \\
\left(\text { Rs. ha }^{-1}\right)\end{array}$ & B:C ratio \\
\hline $\begin{array}{l}T_{1:} P E \text { atrazine at } 0.25 \mathrm{~kg} \mathrm{ha}^{-1} f b \text { hand } \\
\text { weeding at } 25 \text { DAS }\end{array}$ & 43816 & 78585 & 34769 & 1.79 \\
\hline $\begin{array}{l}\mathrm{T}_{2:} \text { PE pendimethalin at } 1 \mathrm{~kg} \mathrm{ha}^{-1} \mathrm{fb} \text { hand } \\
\text { weeding at } 25 \text { DAS }\end{array}$ & 44981 & 76754 & 31773 & 1.71 \\
\hline $\begin{array}{l}\mathrm{T}_{3:} \mathrm{PE} \text { atrazine at } 0.25 \mathrm{~kg} \mathrm{ha}^{-1} \mathrm{fb} \mathrm{POE} \\
\text { tembotrione } 120 \mathrm{~g} \mathrm{ha}^{-1}\end{array}$ & 43948 & 99592 & 55664 & 2.27 \\
\hline $\begin{array}{l}\mathrm{T}_{4:} \text { PE pendimethalin at } 1 \mathrm{~kg} \mathrm{ha}^{-1} \mathrm{fb} \text { POE } \\
\text { tembotrione } 120 \mathrm{~g} \mathrm{ha}^{-1}\end{array}$ & 45113 & 97644 & 52531 & 2.16 \\
\hline $\begin{array}{l}\text { T }_{5: P E} \text { atrazine at } 0.25 \mathrm{~kg} \mathrm{ha}^{-1} \mathrm{fb} \text { POE } \\
\text { halosulfuron methyl } 90 \mathrm{~g} \mathrm{ha}^{-1}\end{array}$ & 45196 & 94812 & 49616 & 2.10 \\
\hline $\begin{array}{l}\text { T }_{6:} \text { PE pendimethalin at } 1 \mathrm{~kg} \mathrm{ha}^{-1} \mathrm{fb} \text { POE } \\
\text { halosulfuron methyl } 90 \mathrm{~g} \mathrm{ha}^{-1}\end{array}$ & 46361 & 93552 & 47191 & 2.02 \\
\hline $\mathbf{T}_{7:}$ Weed free check & 62316 & 102258 & 39942 & 1.64 \\
\hline $\mathbf{T}_{8:}$ Unweeded check & 37836 & 37611 & -224 & 0.99 \\
\hline
\end{tabular}


Similar results were found by Sivamurugan $e t$ al., (2017) and Mritunjay Kumar (2018). The lowest yield attributes and grain yield of maize was resulted with unweeded check (T8). The lowest kernel yield of maize was due to stiff competition from weeds resulting in poor source and sink development with poor yield contributing characters and yield. The results were in accordance with the findings of Sandhya Rani et al., (2019).

\section{Economics}

In respect of economics highest gross return of Rs. $99591 \mathrm{ha}^{-1}$, net return of Rs. $55644 \mathrm{ha}^{-1}$ with the $\mathrm{BC}$ ratio of 2.27 was recorded in $\mathrm{PE}$ atrazine $0.25 \mathrm{~kg} \mathrm{ha}^{-1}$ followed by $\mathrm{POE}$ tembotrione $120 \mathrm{~g} \mathrm{ha}^{-1}\left(\mathrm{~T}_{3}\right)$ (Table 3).

From the field study, it could be concluded that application of PE atrazine $0.25 \mathrm{~kg} \mathrm{ha}^{-1}$ followed by POE tembotrione $120 \mathrm{~g} \mathrm{ha}^{-1}\left(\mathrm{~T}_{3}\right)$ is effective in controlling of weeds compared to other treatments and recorded higher grain yield $\left(\mathrm{kg} \mathrm{ha}^{-1}\right)$ and $\mathrm{B}: \mathrm{C}$ ratio (2.27) and it was followed by application of PE pendimethalin $1 \mathrm{~kg} \mathrm{ha}^{-1}$ followed by POE tembotrione $120 \mathrm{~g}$ $\mathrm{ha}^{-1}\left(\mathrm{~T}_{4}\right)$ which recorded grain yield, B:C ratio of $6510 \mathrm{~kg} \mathrm{ha}^{-1}$, and 2.16 respectively. These two combinations of herbicides were found to be more suitable for obtaining higher grain yield and $\mathrm{B}: \mathrm{C}$ ratio.

\section{Acknowledgement}

I sincerely acknowledge the Tamil Nadu State Council for Science and Technology (TNSCST) in successful completion of my research through their help and support.

\section{References}

Biswas, S., Srabani Debnath, Abhijit Saha and Benukar Biswas. 2018. Weed Management in Maize System in New Alluvial Zone of West Bengal, India.
Int.J.Curr.Microbiol.App.Sci. $\quad 7(4)$ : 1344-1350.

Gomez, K.A, and Gomez, A.A. 1984. Statistical Procedures for Agriculture Research. A Wiley-Inter Science Publication. John Wiley \& Sons, Inc., New York, USA.

Hatti, V., Sanjay, M.T., Ramachandra Prasad, T.V., Kalyanamurthy, K.N., Basavaraj Kumbar and Shruthi, M.K. 2014. Effect of new herbicide molecules on yield, soil microbial biomass and their phytotoxicity on maize (Zea mays L.) under irrigated conditions. The Bioscan. 9(3): 1127-1130.

Mritunjay Kumar., 2018.Halosulfuron Methyl 75\% WG (Sempra) - A New Herbicide for the Control of Cyperus rotundus in Maize (Zea mays L.) Crop in Bihar. Int.J.Curr.Microbiol.App.Sci. 7(3): 841846.

Nazreen, S., D. Subramanyam, N. Sunitha and V. Umamahesh. 2018. Growth and Yield of Maize as Influenced by Sequential Application of Herbicides. Int.J.Curr.Microbiol.App.Sci. 7(5): 2764-2770.

Sandhya Rani, B., V. Chandrika, G. Prabhakara Reddy, P. Sudhakar, K. V. Nagamadhuri and G. Karuna Sagar. 2019 Effect of Weed Management Practices in Rabi Maize and their Residual Effect on Succeeding Greengram. Int.J.Curr.Microbiol. App.Sci. 8(12): 831-837.

Shantveerayyahawaldar and Agasimani.C.A. 2012. Effect of herbicides on weed control and productivity of maize (Zea mays L.). Karnataka J. Agric. Sci. 25 (1): 137-139.

Singh, A. K., C.M. Parihar, S.L. Jat, B. Singh and S. Sharma. 2015. Weed management strategies in maize (Zea mays): Effect on weed dynamics, productivity and economies of maizewheat (Triticum aestivum) cropping 
system in Indogangatic plains. Indian Journal of Agricultural sciences. 85 (1):87-92.

Sivamurugan, A.P., R. Ravikesavan, A.
Yuvaraja, A.K. Singh and S.L. Jat. 2015. Weed Management in Maize with New Herbicides. Chem Sci Rev Lett, 6(22): 1054-1058.

\section{How to cite this article:}

Arockia Infant Paul, R., G. Srinivasan, A. Veeramani and Thamizh Vendan, R. 2020. Effect of Sequential Application of Herbicides on Weed Density, Weed Dry Weight and Yield of Irrigated Maize. Int.J.Curr.Microbiol.App.Sci. 9(10): 1128-1135.

doi: https://doi.org/10.20546/ijcmas.2020.910.135 